\title{
Handbook of Phase Transfer Catalysis
}




\section{JOIN US ON THE INTERNET VIA WWW, GOPHER, FTP OR EMAIL:}

WWW: http://www.thomson.com

GOPHER: gopher.thomson.com

FTP: ftp.thomson.com

A service of ITP $\mathbf{P}^{\text {k }}$

EMAIL: findit@kiosk.thomson.com 


\title{
Handbook of Phase Transfer Catalysis
}

\author{
Edited by \\ Y. Sasson and R. Neumann
}

Casali Institute of Applied Chemistry

The Hebrew University of Jerusalem

Israel

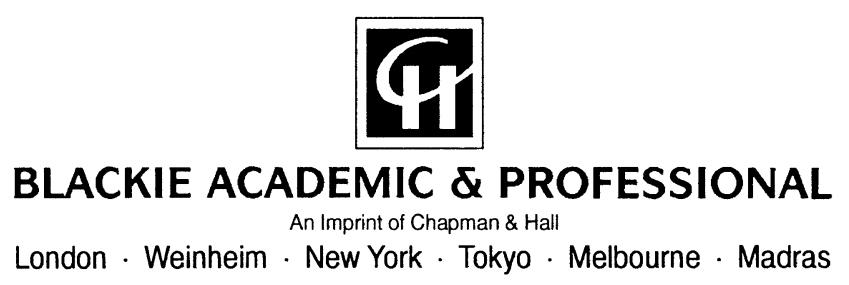


Published by Blackie Academic and Professional, an imprint of Chapman \& Hall, 2-6 Boundary Row, London SE1 8HN, UK

Chapman \& Hall, 2-6 Boundary Row, London SE1 8HN, UK

Chapman \& Hall GmbH, Pappelallee 3, 69469 Weinheim, Germany

Chapman \& Hall USA, 115 Fifth Avenue, New York, NY 10003, USA

Chapman \& Hall Japan, ITP-Japan, Kyowa Building, 3F, 2-2-1 Hirakawacho, Chiyoda-ku, Tokyo 102, Japan

DA Book (Aust.) Pty Ltd, 648 Whitehorse Road, Mitcham 3132, Victoria, Australia

Chapman \& Hall India, R. Seshadri, 32 Second Main Road, CIT East, Madras 600 035, India

First edition 1997

(C) 1997 Chapman \& Hall

Typeset in 10/12pt Times by AFS Image Setters Ltd, Glasgow

ISBN-13:978-0-7514-0258-2 e-ISBN-13:978-94-009-0023-3

DOI: $10.1007 / 978-94-009-0023-3$

Apart from any fair dealing for the purposes of research or private study, or criticism or review, as permitted under the UK Copyright Designs and Patents Act, 1988, this publication may not be reproduced, stored, or transmitted, in any form or by any means, without the prior permission in writing of the publishers, or in the case of reprographic reproduction only in accordance with the terms of the licences issued by the Copyright Licensing Agency in the UK, or in accordance with the terms of licences issued by the appropriate Reproduction Rights Organization outside the UK. Enquiries concerning reproduction outside the terms stated here should be sent to the publishers at the London address printed on this page.

The publisher makes no representation, express or implied, with regard to the accuracy of the information contained in this book and cannot accept any legal responsibility or liability for any errors or omissions that may be made.

A catalogue record for this book is available from the British Library

Library of Congress Catalog Card Number: 96-71964

() Printed on acid-free paper, manufactured in accordance with ANSI/NISO Z39.48-1992 (Permanence of Paper) 


\section{Contents}

List of contributors $\quad$ xi

Preface xiii

1 Nucleophilic aliphatic and aromatic substitution in phase transfer catalysis: mechanism and synthetic applications

I.A. Esikova

1.1 Introduction

1.2 General considerations

1.2.1 Reactions in liquid-liquid systems

1.2.2 The advantages of solid-liquid systems

1.3 Reactivity of anions

The role of water in solid-liquid substitution. The omega phase

1.5 Kinetics and mechanism of PTC substitution

1.6 Design of catalytic system. The role of catalyst, solvent and other factors 14

$\begin{array}{lll}\text { 1.6.1 Catalyst } & 15\end{array}$

$\begin{array}{lll}1.6 .2 & \text { Solvent } & 17\end{array}$

$\begin{array}{llr}1.6 .3 & \text { Stirring } & 19\end{array}$

$\begin{array}{ll}\text { 1.6.4 Concentration of catalyst } & 19\end{array}$

$\begin{array}{ll}\text { 1.6.5 Stability of catalyst } & 20\end{array}$

$\begin{array}{lll}1.7 & \text { Applications } & 20\end{array}$

$\begin{array}{ll}\text { 1.7.1 Synthesis of fluorides } & 20\end{array}$

$\begin{array}{ll}\text { 1.7.2 Synthesis of chlorides } & 21\end{array}$

$\begin{array}{ll}\text { 1.7.3 Synthesis of bromides and iodides } & 22\end{array}$

\begin{tabular}{lll} 
1.7.4 Synthesis of thiocyanates & 22 \\
\hline
\end{tabular}

$\begin{array}{lll}\text { 1.7.5 Synthesis of nitriles } & 23\end{array}$

$\begin{array}{lll}\text { 1.7.6 Synthesis of azides } & 24\end{array}$

$\begin{array}{ll}\text { 1.7.7 Synthesis of nitro compounds } & 24\end{array}$

$\begin{array}{lll}\text { 1.7.8 Synthesis of thiols and sulfides } & 24\end{array}$

$\begin{array}{ll}\text { 1.7.9 Trichloromethyl anion substitution } & 25\end{array}$

$\begin{array}{ll}\text { 1.7.10 Hydrolysis and saponification } & 25\end{array}$

$\begin{array}{lll}1.7 .11 & \text { Esterfication } & 25\end{array}$

$\begin{array}{ll}\text { 1.7.12 PTC in carbohydrate chemistry } & 26\end{array}$

$\begin{array}{ll}\text { 1.7.13 Aromatic nucleophilic substitution } & 26\end{array}$

$\begin{array}{ll}\text { 1.7.14 PTC in polymer chemistry } & 29\end{array}$

1.7.15 Some industrial applications of PTC substitution 30

1.8 Conclusion $\quad 31$

$\begin{array}{ll}\text { References } & 32\end{array}$

2 Kinetic modelling of catalytic phase transfer systems 36

M.-L. Wang

2.1 Introduction

2.2 Two-phase phase transfer catalytic reactions

36

2.2.1 Normal phase transfer catalysis (NPTC) 36

2.2.2 Reverse phase transfer catalysis (RPTC) 79

2.2.3 Inverse phase transfer catalysis (IPTC) 79 
2.3 Three-phase phase transfer catalytic (TPPRC) reactions

2.3.1 Synthesis of hexachlorocyclotriphosphazene by triphase catalysis 95

$\begin{array}{ll}2.3 .2 & \text { Dynamic model of triphase catalysis } \\ 2.300\end{array}$

2.3.3 A pseudo-steady-state hypothesis for triphase catalysis 103

References

3 Synthesis of quatemary ammonium salts

Y. Sasson

3.1 Introduction 111

3.2 Direct quaternization 111

3.3 Liquid-liquid anion exchange 113

$\begin{array}{lll}3.4 & \text { Solid-liquid anion exchange } & 115\end{array}$

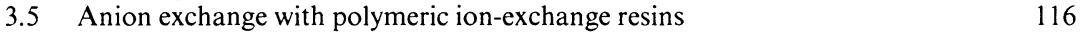

3.6 Quat hydroxides via a two-stage anion exchange 117

3.7 Transformation of the anion 118

$\begin{array}{ll}\text { 3.7.1 Reaction with acids: neutralization of hydroxide } & 118\end{array}$

$\begin{array}{ll}\text { 3.7.2 Decomposition of anions } & 118\end{array}$

$\begin{array}{lll}3.8 & \text { Temperature-stable phase transfer catalysts } & 123\end{array}$

$\begin{array}{ll}3.9 & \text { Catalyst recovery and recycle } \\ 3 & 127\end{array}$

$\begin{array}{ll}3.10 & \text { Typical procedures } \\ & 128\end{array}$

$\begin{array}{ll}3.10 .1 & \text { Tributylbenzylammonium cyanide } \\ 3 & 128\end{array}$

$\begin{array}{ll}3.10 .2 & \text { Tetrabutylammonium chloride (TBAC) } \\ 3.128\end{array}$

$\begin{array}{lll}3.10 .3 & \text { Synthesis of tetrahexylammonium formate (THAFor) } & 128\end{array}$

3.10.4 Tricaprylmethylammonium fluoride (Aliquat 336-F) 128

$\begin{array}{lll}3.10 .5 & \begin{array}{l}\text { Preparation of tetra- } \boldsymbol{n} \text {-octylammonium hydroxide (TOAH) and } \\ \text { tetra- } \boldsymbol{n} \text {-butylammonium hydroxide (TBAH) }\end{array} & 129\end{array}$

3.10.6 N-(2-Ethylhexyl)-4-dimethylaminopyridinium chloride $\quad 129$

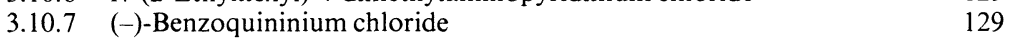

3.10 .8 (+)- $N$-(4- Trifluoromethyl)benzyldihydrocinchonium bromide $\quad 130$

$3.10 .9(-)-N-(9-$ Fluorenyl)quininium bromide $\quad 130$

3.10.10 Tetra- $n$-butylammonium bibenzoate $\quad 130$

3.10.11 Dihexyltetramethylguanidinium bromide $\quad 130$

References

\section{Phase transfer catalyzed reactions under basic conditions}

M. Makosza and M. Fedoryński

4.1 Introduction and mechanistic picture 135

4.2 Applications of phase transfer catalysis in reactions of organic anions 137

$\begin{array}{lll}\text { 4.2.1 Reactions of carbanions with alkylating agents } & 137\end{array}$

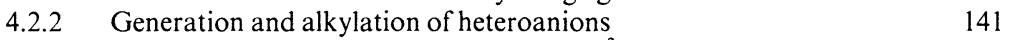

$\begin{array}{lll}\text { 4.2.3 Reactions of carbanions at electrophilic } \mathrm{sp}^{2} \text { carbon } & 143\end{array}$

4.2.4 Reactions of carbanions with heteroatom electrophiles $\quad 149$

4.3 Generation and reactions of carbenes 151

$\begin{array}{lll}\text { 4.3.1 Dihalocarbenes } & 151\end{array}$

4.3.2 Other carbenes $\quad 156$

$\begin{array}{lll}4.4 & \beta \text {-Elimination } & 158\end{array}$

$\begin{array}{ll}\text { 4.5 General conclusions } & 160\end{array}$

$\begin{array}{ll}\text { Abbreviations } & 161\end{array}$

References 162 
5 Application of phase transfer catalysis in the chemical industry

M. Sharma

5.1 Phase transfer catalysis in industrial processes 168

5.2 Evaluation and optimization PTC options 168

5.3 Applications based on benzyl chloride 169

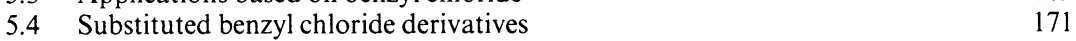

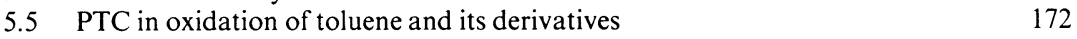

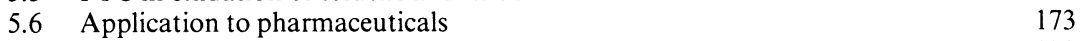

$\begin{array}{lll}\text { 5.6.1 } N \text {-Alkylation } & 173\end{array}$

5.6.2 Preparation of antitumor agents from estradiols by PTC 175

5.6.3 PTC method for production of lysergic acid-based drugs $\quad 176$

$\begin{array}{lll}5.7 & \text { PTC with activated oxygen carrier } & 177\end{array}$

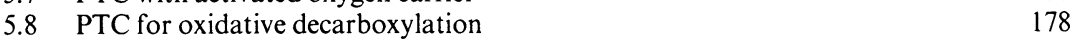

$\begin{array}{ll}5.9 \text { Halogen exchange } & 180\end{array}$

$\begin{array}{lll}5.10 & \text { Application of PTC to dyes } & 182\end{array}$

$\begin{array}{lll}5.10 .1 & \text { Sulfite displacement reaction } & 183\end{array}$

5.10.2 Monsanto's environmentally safer route to aromatic amines 183

5.11 Application of PTC to polymers 183

$\begin{array}{lll}5.11 .1 & \text { Nylon-8 } & 185\end{array}$

$\begin{array}{lll}5.11 .2 & \text { Triaryl phosphates (TAPs) } & 185\end{array}$

$\begin{array}{ll}5.12 & \text { Application of PTC to agrochemicals } \\ 5 & 187\end{array}$

$\begin{array}{ll}5.13 \text { Miscellaneous reactions } & 190\end{array}$

5.13.1 Alkyl halides from primary alcohols $\quad 190$

$\begin{array}{ll}5.13 .2 \text { Oximation } & 190\end{array}$

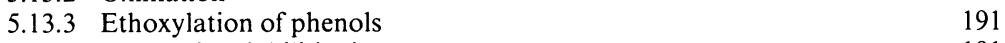

5.13.4 Converting liabilities into assets 191

5.13.5 $\mathrm{CO}_{2}$ absorption in salt hydrates $\quad 192$

5.14 Some examples of deuterium-labeled compounds (H-D exchange) 192

5.15 Use of PTC in named organic ractions 193

$\begin{array}{ll}5.15 .1 \text { Aldol reaction } & 193\end{array}$

5.15.2 Michael reaction 193

$\begin{array}{lll}5.15 .3 \text { Darzen reaction } & 193\end{array}$

$\begin{array}{ll}\text { 5.15.4 Williamson ether synthesis } & 194\end{array}$

$\begin{array}{ll}\text { 5.15.5 Wittig reaction } & 194\end{array}$

$\begin{array}{ll}\text { 5.15.6 Horner-Emmons reaction } & 194\end{array}$

$\begin{array}{ll}5.15 .7 \text { Reimer-Tiemann reaction } & 194\end{array}$

$\begin{array}{ll}5.15 .8 \text { Hofmann rearrangement } & 194\end{array}$

5.16 Separation and recovery of phase transfer catalyst 195

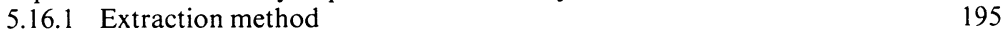

5.16.2 Distillation method 196

\begin{tabular}{ll}
5.17 Wastewater treatment & 196 \\
\hline
\end{tabular}

$\begin{array}{ll}\text { References } & 197\end{array}$

6 Phase transfer catalysis in polymer synthesis 200

L.H. Tagle

6.1 Introduction 200

$\begin{array}{ll}6.2 \text { Polyethers } & 201\end{array}$

$\begin{array}{ll}6.3 \text { Polyesters } & 211\end{array}$

$\begin{array}{ll}6.4 \text { Polycarbonates } & 219\end{array}$

$\begin{array}{ll}6.5 & \text { Polythiocarbonates } \\ 6.6 & 224\end{array}$

6.6 Polythioethers, polysulfonates and polysulfones 228

$\begin{array}{ll}6.7 \text { Copolymers } & 231\end{array}$

$\begin{array}{ll}6.8 \text { Carbon-carbon chain polymers } & 236\end{array}$

6.9 Miscellaneous polymers 238

$\begin{array}{ll}\text { References } & 240\end{array}$ 
7 Phase transfer catalysis in carbohydrate chemistry

R. Roy

7.1 Introduction

7.2 Non anomeric transformations $\quad 245$

$\begin{array}{lll}\text { 7.2.1 Introduction of protecting groups } & 245\end{array}$

$\begin{array}{ll}\text { 7.2.2 Oxidation and reduction } & 253\end{array}$

$\begin{array}{ll}\text { 7.2.3 } \mathrm{C}-\mathrm{C} \text { bond-forming reactions } & 255\end{array}$

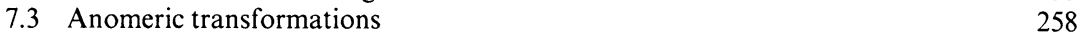

$\begin{array}{lll}7.3 .1 & O \text {-Glycosides } & 261\end{array}$

$\begin{array}{lll}\text { 7.3.2 } S \text {-Glycosides } & 263\end{array}$

$\begin{array}{lll}\text { 7.3.3 Others } & 264\end{array}$

$\begin{array}{lll}7.4 & \text { Nucleosides } & 265\end{array}$

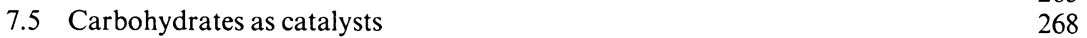

$\begin{array}{ll}7.6 \text { Conclusions } & 271\end{array}$

$\begin{array}{ll}\text { References } & 272\end{array}$

8 Phase transfer catalysis in heterocyclic chemistry 276

E. Díez-Barra and A. de la $\mathrm{Hoz}$

$\begin{array}{ll}8.1 \text { Introduction } & 276\end{array}$

8.2 Synthesis of heterocyclic systems $\quad 276$

8.2.1 Substitution at a saturated carbon atom 276

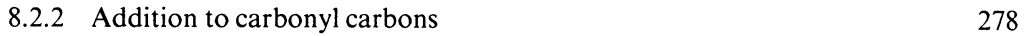

8.2.3 Addition to activated double and triple bonds 281

8.2.4 Epoxidation addition of carbenes and nitrenes $\quad 283$

$\begin{array}{lll}8.2 .5 & \text { Electrocyclic reactions } & 285\end{array}$

8.2.6 Cycloaddition reactions 286

8.2.7 Ring transformations 286

$\begin{array}{lll}8.3 & \text { Reactivity of heterocyclic systems } & 287\end{array}$

8.3.1 Heterocycles as nucleophiles $\quad 287$

8.3.2 Heterocycles as electrophiles 296

$\begin{array}{ll}8.4 \text { Heterocycles as phase transfer catalysts } & 299\end{array}$

$\begin{array}{ll}\text { 8.4.1 Normal phase transfer agents } & 299\end{array}$

$\begin{array}{ll}\text { 8.4.2 Chiral phase transfer agents } & 301\end{array}$

8.4.3 Inverse phase transfer catalysis (IPTC) 307

8.4.4 Electron transfer catalysis (ETC) 308

$\begin{array}{ll}\text { References } & 309\end{array}$

9 Phase transfer catalysis in oxidation processes 317

M. Hronec

$\begin{array}{lll}9.1 & \text { Introduction } & 317\end{array}$

$\begin{array}{lll}9.2 & \text { Reagents } & 318\end{array}$

$\begin{array}{lll}9.2 .1 & \text { Permanganate and chromate anions } & 318\end{array}$

$\begin{array}{ll}\text { 9.2.2 Hypochlorite } & 318\end{array}$

$\begin{array}{ll}9.2 .3 \text { Hydrogen peroxide } & 319\end{array}$

$\begin{array}{ll}9.2 .4 \text { Molecular oxygen } & 319\end{array}$

$\begin{array}{ll}\text { 9.2.5 Other oxidants } & 320\end{array}$

$\begin{array}{lll}9.3 & \text { Synthetic utility } & 321\end{array}$

9.3.1 Oxidation of hydrocarbons $\quad 321$

9.3.2 Oxidation of oxygen-containing compounds 325

$\begin{array}{ll}\text { 9.3.3 Oxidation of nitrogen compounds } & 327\end{array}$

$\begin{array}{ll}\text { 9.3.4 Oxidation of sulfur compounds } & 328\end{array}$

$\begin{array}{lll}9.4 & \text { Future prospects } & 329\end{array}$

References $\quad 330$ 
10 Organometallic reactions under phase transfer conditions

I. Amer

$\begin{array}{ll}\text { Abbreviations } & 336\end{array}$

$\begin{array}{lll}10.1 & \text { Introduction } & 336\end{array}$

10.2 Phosphorus donor-phase transfer agent hybrid ligands 337

10.3 Separate phase transfer agent and organometallic species $\quad 340$

$\begin{array}{ll}\text { 10.3.1 Stoichiometric reactions } & 340\end{array}$

$\begin{array}{ll}\text { 10.3.2 Catalysed reactions } & 344\end{array}$

$\begin{array}{lll}10.4 & \text { Conclusions } & 366\end{array}$

References $\quad 366$

11 Sonochemical and microwave activation in phase transfer catalysis 369

A. Loupy and J.-L. Luche

$\begin{array}{llr}11.1 & \text { Introduction } & 369 \\ 11.2 & \text { Sonochemistry } & 369 \\ & 11.2 .1 \quad \text { Principles of sonochemical reactivity } & 370 \\ 11.2 .2 & \text { Synthetic applications in phase transfer processes } & 373 \\ 11.2 .3 \quad \text { Conclusion } & 385 \\ 11.3 & \text { Microwave chemistry } & 385 \\ 11.3 .1 \quad \text { Principles of microwave activation } & 386 \\ 11.3 .2 \quad \text { Synthetic applications in phase transfer processes } & 390 \\ \text { 11.3.3 Conclusion } & 400 \\ \text { References } & 401\end{array}$

12 Analytical applications of phase transfer catalysis 405

C. de Ruiter and H. Lingeman

$\begin{array}{lll}12.1 & \text { Introduction } & 405\end{array}$

12.2 Analytical applications of liquid-liquid PTC 406

12.3 Analytical applications of solid-liquid PTC 414

12.4 Analytical applications of micellar PTC 418

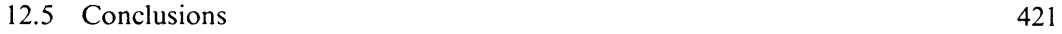

References $\quad 421$

13 Triphase catalysis $\quad 424$

M. Tomoi

13.1 Introduction $\quad 424$

13.2 General methods for preparation of triphase catalysts $\quad 424$

13.3 Fundamental process of triphase catalysis 427

13.4 Effect of reaction conditions 430

13.5 Structure/properties and activity of triphase catalysts 433

13.5.1 Catalyst particle size 433

13.5.2 Active site structure and chemical structure of the polymer support 434

13.5.3 Cross-linking level 440

13.5.4 Catalyst loading level (ring substitution) 440

13.5.5 Space-chain effect 445

13.5.6 Morphology of polymer support 448

13.6 Problems with the practical use of triphase catalysts 453

13.6.1 Stability of triphase catalysts $\quad 453$

13.6.2 Synthetic applications $\quad 454$

13.6.3 Chemical engineering of triphase catalysis 457

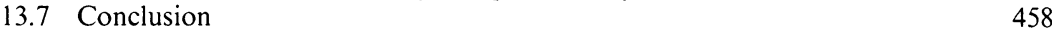

References $\quad 458$ 
14 Chiral phase transfer catalysis

\section{T. Shioiri}

14.1 Introduction

14.2 Chiral phase transfer catalysts

14.3 Asymmetric phase transfer reactions $\quad 463$

14.3.1 Carbon-carbon bond formation $\quad 463$

$\begin{array}{lll}\text { 14.3.2 } & \text { Oxidation } & 471\end{array}$

14.3.3 Reduction $\quad 476$

14.3.4 Carbon-nitrogen bond formation 476

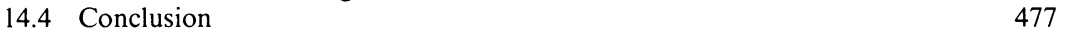

$\begin{array}{ll}\text { References } & 478\end{array}$

15 Chemical modification of polymers via phase transfer catalysis 480

T. Nishikubo

15.1 Introduction

15.2 Progress in chemical modification of polymers from the classical method to phase transfer catalysis

15.3 Chemical modification of polymers with pendant haloalkyl groups using phase transfer catalysis

15.3.1 Substitution reactions of poly[(chloromethyl)styrene] using phase transfer catalysis

15.3.2 Substitution reactions of other polymers containing pendant haloalkyl and haloaryl groups using phase transfer catalysis

15.3.3 Elimination reactions of polymers containing pendant haloalkyl groups using phase transfer catalysis

15.4 Synthesis of functional polymers by reactions of polymers containing pendant haloalkyl groups using phase transfer catalysis

15.5 Limitations of chemical modification of polymers using phase transfer catalysis 503

15.6 Chemical modification of polymers with pendant cyclic ether groups using new activity of phase transfer catalysts

15.7 Conclusion

References

16 Phase transfer catalysis of uncharged species

$\begin{array}{llr}16.1 & \text { Introduction } & 510 \\ 16.2 & \text { Water } & 510\end{array}$

$\begin{array}{lll}16.3 & \text { Hydrogen halides } & 512\end{array}$

$\begin{array}{lll}16.4 & \text { Hydrogen cyanide } & 515\end{array}$

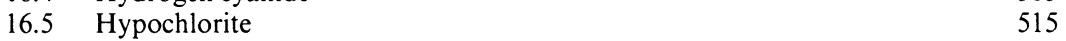

16.6 Hydrogen peroxide and alkyl hydroperoxides 518

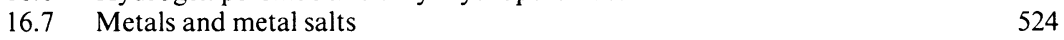

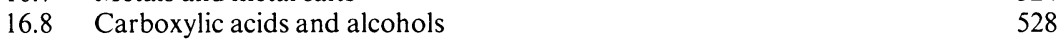

16.9 Carbon acids $\quad 531$

16.10 Ammonia and amines $\quad 532$

16.11 Ammonium polyhalide complexes $\quad 533$

$\begin{array}{ll}\text { 16.12 Inverse phase transfer catalysis } & 535\end{array}$

$\begin{array}{ll}\text { References } & 538\end{array}$

$\begin{array}{ll}\text { Index } & 547\end{array}$ 


\section{Contributors}

I. Amer

A. de la Hoz

C. de Ruiter

E. Díez-Barra
The Institute for Applied Research, Ben-Gurion University of the Negev, P.O. Box 653, Beer-Sheva 84105, Israel

Department of Inorganic, Organic and Biochemistry, University of Castilla la Mancha, E13071 Ciudad Real, Spain

Ahzo Nobel Chemistry Service Unit Laboratory, P.O. Box 124, 9930 AC Welfzÿl, The Netherlands

Department of Inorganic, Organic and Biochemistry, University of Castilla la Mancha, E13071 Ciudad Real, Spain

I.A. Esikova Chiron Corporation, Pharmaceutical Research and Development, Emeryville, California 94608-2016, USA

M. Fedoryński Department of Chemistry, Technical University, Warsaw, Poland

M. Hronec Department of Organic Technology, Slovak Technical University, 81237 Bratislava, Slovak Republic

H. Lingeman Department of Analytical Chemistry, Free University, De Boelelaan 1083, 1081 HV Amsterdam, The Netherlands

A. Loupy

Laboratoire des Réactions Sélectives sur Supports, URA du CNRS 478, Institut de Chimie Moléculaire d'Orsay, Université Paris-Sud, Bat. 410, 91405 Orsay Cedex, France

J.-L. Luche Laboratoire de Chimie Moléculaire et Environment, Université de Savoie - ESIGEC, 73376 Le Bourget du Lac, France

M. Mạkosza Institute of Organic Chemistry, Polish Academy of Sciences, Warsaw, Poland

R. Neumann Casali Institute of Applied Chemistry, The Hebrew University of Jerusalem, Jerusalem 91904, Israel 
T. Nishikubo Department of Applied Chemistry, Faculty of Engineering, Kanagawa University, Rokkakubashi, Kanagawa-ku, Yokohama 221, Japan

R. Roy Department of Chemistry, University of Ottawa, Ontario, KIN 6N5, Canada

Y.Sasson Casali Institute of Applied Chemistry, The Hebrew University of Jerusalem, Jerusalem 91904, Israel

M. Sharma Department of Chemical Technology, University of Bombay, Matunga, Bombay 400019, India

T. Shioiri Faculty of Pharmaceutical Sciences, Nagoya City University, Tanabe-dori, Mizuho-ku, Nagoya 467, Japan

L.H. Tagle Organic Chemistry Department, Faculty of Chemistry, Catholic University of Chile, P.O. Box 306, Santiago 22, Chile

M. Tomoi Department of Applied Chemistry, Faculty of Engineering, Yokohama National University, Yokohama, Japan

M.-L. Wang Department of Chemical Engineering, National Tsing Hua University, Hsinchu, Taiwan 30043, ROC 


\section{Preface}

Even though phase transfer catalysis was described as a 'mature' discipline with 'standard' methods [1], we have witnessed over the past twelve years a continuous flow of new scientific papers and patents dealing with phase transfer topics and new applications at an almost constant annual rate of 300 to 320 articles and 70 to 80 new patents per year. At the beginning of March 1997 , over 6200 references could be retrieved from the chemical abstracts under the term 'Phase Transfer Catalysis'.

Browsing through recent references, one can conclude that PTC has evolved from a mere, though significant, improvement of aliphatic substitution reactions into previously unforeseen domains. Phase transfer is presently a basic tool in polymer chemistry, heterocyclic chemistry, organometallic synthesis and pharmaceutical and agrochemical manufacture [2]. A major recent evolution is the introduction of PTC into chemistry related to the environment. Phase transfer methods are currently being applied to the revision of production processes, for example by elimination of solvents [3]. Another new application is the decomposition of poisonous effluents, such as PCBs at low PPM levels [4]. The development of novel highly sensitive analytical methods based on PTC is now practiced for a vast spectrum of analytical applications. For instance, PTC methods are used in the medical laboratory in the determination of estrogen in human serum [5], in the forensic laboratory for detection of post explosion residues [6] and in the geochemical laboratory for assay of organic matter in Arctic surface sediments [7].

Other new frontiers are developing rapidly. For example, supercritical fluids [8] such as carbon dioxide are now being used as unique PTC solvents, ultrasonic and microwave equipment are being introduced into the PTC arena and highly refined biomaterials such as carbohydrates or proteins are being processed and synthesized. Quaternary ammonium salts are used to stabilize colloidal metallic nano-particles [9]. Species like sodium metal [10], sodium hydride [11] or potassium tert-butoxide [12] are now being extracted by phase transfer agents and catalytic effects are clearly observed in highly polar solvents such as DMF or DMSO in the presence of PT catalysts. The classical direction of the phase transfer extraction process has been reverted with the introduction of inverse PTC - catalysis for transport of reactive species from organic phase into water. New structures phase transfer catalysts are being developed including chiral, temperature stable and multifunctional catalysts. These are all presently available and are effective tools in the hands of the synthetic or process chemist. The important issue of catalyst 
recovery and recycle has now been addressed with new methods recently introduced [13].

Numerous patents based on PTC technology are being issued to major multinational chemical companies such as General Electric, DuPont, Dow, Bayer, Zeneca, Ciba-Geigy, Merck, Eli Lilly and Sumitomo. The major driving force for industrial application of PTC was attributed to increasing reaction rate (reduction of cycle time) and replacing, reducing or eliminating solvents [14].

This volume aspires to address these and other new developments in the area of phase transfer catalysis, along with the recounting of some fundamental concepts, without repeating the large amount of material that has been discussed in depth in the previous excellent books in the field. As for future trends, we believe that essentially any heterogeneous reaction or separation system, either in the micro-, or the macroscale may call for the application of phase transfer concepts. We believe that numerous new applications in synthesis, separation and assay of new materials and active molecules are just around the corner.

We wish to extend our gratitude to our highly competent and authoritative writers and to the professional team at Chapman \& Hall who made this book possible.

Yoel Sasson and Ronny Neumann

Jerusalem, March 1997

\section{References}

1. Dehmlow, E.V. and Dehmlow, S.S. (1993) Phase Transfer Catalysis 3rd Edn, Verlag Chemie, Weinheim.

2. Starks, C., Liotta, C., Halpern, M. (1994) Phase-Transfer Catalysis: Fundamentals, applications and industrial perspectives, Chapman \& Hall, New York.

3. Tavener, S. and Clarck, J.H. (1997) Chem. Ind., 22.

4. Tsunoda, H. (1996) Jpn Pat., 08290053. Chem. Abst., 126, 74545.

5. DeSilva, K.H., Vest, F.B. and Karnes, H.T. (1996) Biomed. Chromatogr., 10, 318.

6. Glattstein, B., Abromovici-Bar, S., Tamiri, T. and Zitrin, S. (1995) 5th Int. Symp. Anal. Detect. Explosives, Va USA.

7. Zegouagh, Y., Derenne, S., Largeau, C. and Saliot, A. (1996) 24, 841.

8. Turner, R.J. (1995) Proc. Annu. Meet. - Air Waste Manage. Assoc., 15, 91. Chem.Abstr., 126, 36403 .

9. Reetz, M.T., Helbig, W., Quaiser, S.A., Stimming, U., Breuer, N. and Vogel, R. (1995) Science, 267, 367.

10. Jones, R.G., Budnik, U., Holder, S.J., Wong, W.K.C. (1996) Macromolecules, 29, 8036.

11. Mitamura, S. and Jodai, H. (1996) Jpn Pat., 08268950. Chem. Abstr., 126, 31184.

12. Lazrek, H.B., Taourite, M., Barascut, J.L. and Imbach, J.L. (1996) Bull. Soc. Chim. Belg., 105,391 .

13. Ido, T. and Goto, S. (1996) Hyomen, 34, 449. Chem. Abstr., 125, 285920.

14. Halpern, M. (1996) Spec. Chem., 16, 170. 